\title{
ANALISIS PENGARUH PENINGKATAN FREKUENSI PENERBANGAN DAN FASILITAS PARKIR TERHADAP KEPUASAN PELANGGAN DI PARKIR BANDARA HALIM PERDANAKUSUMA JAKARTA TIMUR
}

\author{
Sri Yanthy Yosepha dan Tri Juniman Zai
}

\author{
Abstract
}

This study aimed to examine the effect of the analysis the increase in flight and parking facilities to the level of customer satisfaction at the parking Halim Perdanakusuma Airport empirically, either partially and simultaneously.

The t-test increases in the frequency flight variables can be seen that thitung for increase in flight service by 8.222. $T_{\text {hitung }}$ then compared with the value $t_{\text {tabel, }}$ you are looking at $\alpha=5 \%: 2=2.5 \%$ (test 2 sides) with degrees of freedom (df) $n-k-1$ or (100) 30-2-1. Where $n$ is the number of samples and $k$ is the number of independent variables. Based on these calculations, we obtained $t_{\text {tabel }} 1.984$. This means $t_{\text {hitung }}>t_{\text {tabel }}$.

The t-test parking facilities variables can be seen that thitung to the variable parking facilities by 4.760. $T_{\text {hitung }}$ then compared with the value $t_{\text {tabel, }}$ you are looking at $\alpha=5 \%: 2=2.5 \%$ (test 2 sides) with degrees of freedom (df) $n-k-1$ or (29) 30-2-1. Where $n$ is the number of samples and $k$ is the number of independent variables. Based on these calculations, in can $t_{\text {tabel }} 1.984$. This means $t_{\text {hitung }}>t_{\text {tabel }}$.

The results of the test $F$ can $F_{\text {hitung }} 40.202 . F_{\text {hitung }}$ value is then compared with the value $F_{\text {tabel }}$ sought by the $95 \%$ confidence level, $\alpha=5 \%$, with $1 d f$ (number of variable-1) or 3-1 = 2, and df 2 (nk-1) or 100-2-1, Based on these calculations, obtained $F_{\text {tabel }} 3.090$, thus $F_{\text {hitung }}>F_{\text {tabel }}$.

Key word ; frequency flight, parking facilities, customer satisfaction

\section{PENDAHULUAN}

\section{a. Latar Belakang Masalah}

Pelayanan jasa penerbangan sudah menjadi kebutuhan, bukan saja penduduk berpendapatan tinggi, tetapi sudah menjadi kebutuhan masyarakat berpendapatan sedang dan rendah. Kegiatan lalu lintas penerbangan membutuhkan tersedianya fasilitas bandar udara. Peningkatan kualitas dan kepuasan konsumen atau pelanggan.hal yang harus diperhatikan.

Kepuasan konsumen adalah tingkat perasaan konsumen setelah membandingkan antara apa yang dia terima dan harapannya (Umar, 2005:65). Seorang pelanggan, merasa puas dengan nilai yang diberikan oleh produk atau jasa, sangat besar kemungkinannya menjadi pelanggan dalam waktu yang lama. Demikian juga halnya, setiap orang yang mau datang ke bandara. Apakah orang itu sebagai penumpang (passanger), penjemput, karyawan, atau siapapun itu yang berkepentingan untuk ke bandara, pasti sangat mengharapkan untuk dapat dengan cepat sampai ke tempat tujuan dan mendapat pelayanan yang prima khususnya pelayanan parkirnya.

Penerbangan adalah satu kesatuan sistem yang terdiri atas pemanfaatan wilayah udara, pesawat udara, bandar udara, angkutan udara, navigasi penerbangan, keselamatan, dan keamanan, lingkungan hidup, serta fasilitas penunjang, dan fasilitas umum lainnya yang memerlukan transit untuk menyimpan atau meletakkan kendaraan di tempat parkir.

Bandar Udara Internasional Halim Perdanakusuma sebagai Markas Komando 
Operasi Angkatan Udara I (Koops AU

I) TNI-AU. dan beroperasi, sementara menjadi bandara komersial mulai tanggal 10 Januari 2014 yaitu untuk mengalihkan penerbangan dari Bandara SoekarnoHatta yang dinilai telah penuh sesak. Untuk itu di tahun 2014 bandara Halim perdanakusuma melakukan penerbangan berjadwal (scedule airline) dan penerbangan tidak berjadwal (non scedule airline). Penerbangan berjadwal (scedule airline) yaitu penerbangan yang beroperasi dengan jadwal yang telah ditetapkan dan begitu sebaliknya.

Tabel 1

Maskapai dan Jumlah Penerbangan Tahun 2014-2016

\begin{tabular}{|c|l|c|c|c|c|c|c|}
\hline \multirow{2}{*}{ NO } & \multirow{2}{*}{ AIRLINES } & \multicolumn{2}{|c|}{2014} & \multicolumn{2}{c|}{2015} & \multicolumn{2}{c|}{2016} \\
\cline { 3 - 8 } & & $\begin{array}{c}\text { DEP/ } \\
\text { DAY }\end{array}$ & $\begin{array}{c}\text { ARR/ } \\
\text { DAY }\end{array}$ & $\begin{array}{c}\text { DEP/ } \\
\text { DAY }\end{array}$ & $\begin{array}{c}\text { ARR/ } \\
\text { DAY }\end{array}$ & $\begin{array}{c}\text { DEP/ } \\
\text { DAY }\end{array}$ & $\begin{array}{c}\text { ARR/ } \\
\text { DAY }\end{array}$ \\
\hline 1 & CITILINK & 17 & 17 & 20 & 20 & 28 & 28 \\
\hline 2 & SUSI AIR & 4 & 4 & 4 & 4 & 3 & 3 \\
\hline 3 & BATIK AIR & - & - & 26 & 26 & 30 & 30 \\
\hline 5 & WINGS AIR & - & - & - & - & 3 & 3 \\
\hline \multicolumn{2}{|c|}{ TOTAL } & 21 & 21 & 50 & 50 & 64 & 64 \\
\hline
\end{tabular}

Sumber: Informasi Penerbangan Halim Perdanakusuma International Airport 2016

Berdasarkan tabel diatas, penerbangan pada tahun 2014 yang beroperasi ada dua maskapai yaitu Citilink dan Susi Air, dengan jumlah penerbangan 42 perhari, kedatangan 21 dan keberangkatan 21.

Kemudian pada tahun 2015 maskapai Batik Air masuk dengan 52 penerbangan masing-masing dengan keberangkatan 26 penerbangan dan kedatangan 26 penerbangan. Sedangkan maskapai Citilink sendiri mengalami kenaikan jumlah penerbangan yaitu 40 penerbangan, dari yang sebelumnya 34 penerbangan.

Lebih lanjut, pada tahun 2016 jumlah penerbangan semakin meningkat dengan total 128 penerbangan perhari. Keberangkatan 64 penerbangan dan kedatangan 64 penerbangan, dengan total 4 maskapai penerbangan komersil yang beroperasi.

Kendaraan yang keluar masuk di bandara sangat padat karena keterbatasan parkir dimana terdapat peningkatan frekuensi penerbangan terjadwal dan tidak terjadwal sehingga orang-orang yang berkepentingan dan beroperasi di bandara Halim Perdanakusuma memerlukan persinggahan dan menitipkan kendaraannya ditempat parkir. 


\section{b. Rumusan Masalah}

Berdasarkan hal tersebut penulis mengemukakan rumusan masalah yaitu:

1) Adakah pengaruh peningkatan frekuensi penerbangan terhadap kepuasan pelanggan di parkir Bandara Halim Perdanakusuma?

2) Adakah pengaruh fasilitas parkir terhadap kepuasan pelanggan di Parkir Bandara Halim Perdanakusuma?

3) Adakah pengaruh peningkatan frekuensi penerbangan dan fasilitas parkir terhadap kepuasan pelanggan di parkir Bandara Halim Perdanakusuma?

\section{c. Tujuan Penelitian}

Tujuan dari penelitian ini adalah untuk mengetahui :

1) Pengaruh peningkatan frekuensi penerbangan terhadap kepuasan pelanggan di parkir Bandara Halim Perdanakusuma?

2) Pengaruh fasilitas parkir terhadap kepuasan pelanggan di Parkir Bandara Halim Perdanakusuma?

3) Pengaruh peningkatan frekuensi penerbangan dan fasilitas parkir terhadap kepuasan pelanggan di parkir Bandara Halim Perdanakusuma?

\section{TINJAUAN PUSTAKA}

\section{a. Peningkatan Frekuensi Penerbangan}

Definisi Penerbangan sesuai dengan Undang-undang No. 1 Tahun 2009, Pasal 1 angka 1, adalah satu kesatuan sistem yang terdiri atas pemanfaatan wilayah udara, pesawat udara, angkutan udara, navigasi penerbangan, keselamatan dan keamanan, lingkungan hidup, serta fasilitas penunjang dan fasilitas umum lainnya.

Dimana penerbangan adalah suatu kegiatan yang mempunyai karakteristik dan keunggulan tersendiri, dikembangkan agar mampu meningkatkan pelayanan yang lebih luas, baik domestik maupun internasional. Pengembangan penerbangan ditata dalam satu kesatuan sistem dengan mengintegrasikan prasarana dan sarana penerbangan, metoda, prosedur, dan peraturan sehingga berdaya guna serta berhasil guna bagi pelayanan penerbangan.

Menurut Laurensius Manurung (2010:36), dalam bukunya Strategi dan Inovasi Model Bisnis Meningkatkan Kinerja Usaha, secara menyeluruh, perkembangan industri penerbangan didunia menunjukkan bahwa perusahaan penerbangan dapat berhasil baik jika tidak diregulasi secara ketat (Michel dan Shaked, 1984; Morrison et al., 1989; Ramaswamy et al., 1994; Alam dan Sickles, 2000). Deregulasi pada industri penerbangan umumnya akan berpengaruh terhadap perubahan struktur industri (Beneish 1991; Manuel dan Bonilla, 2008; Damuri dan Anas 2008) dan model bisnis yang berkembang (e.g. Franke, 2007; Dennis, 2007), pada akhirnya berdampak pada peningkatan kinerja industri penerbangan (Ramaswamy et al., 1994). 
Laurensius Manurung (2010:39) mengatakan bahwa pertumbuhan ekonomi berdampak pada meningkatnya daya beli masyarakat yang pada akhirnya berkontribusi besar pada peningkatan permintaan kebutuhan angkutan udara (Bailey, 2002; Lin et al., 2006).

Laurensius Manurung (2010:39), lebih lanjut mengatakan bahwa pertumbuhan jumlah penumpang angkutan udara di Indonesia meningkat sangat tajam sejak adanya pertumbuhan ekonomi yang positif pada tahun 2000. Fakta empiris menunjukkan bahwa pertumbuhan ekonomi Indonesia pada tahun 2000 sekitar 3\% membawa dampak pada meningkatnya jumlah penumpang domestik hingga 20\%. Lebih lanjut, pertumbuhan penumpang menunjukkan angka yang fantastis pada tahun 2003 yang mencapai $55,8 \%$ dan terus berlanjut hingga 2007 dengan rata-rata pertumbuhan di atas $20 \%$ per tahun sejak tahun 2000 (Ditjen Hubud, 2007).

Laurensius Manurung (2010:40), Industri penerbangan merupakan salah satu industri paling dinamis didunia. Pasar industri penerbangan bergantung pada struktur pasar, kebiasaan travel, dan tipe pelanggan dan geografis wilayah (Cerasani, 2002).

Berdasarkan data dari Airports Council International (ACI) dan dikomparasikan dengan data Direktorat Jenderal Perhubungan Udara (DJU), data PT Angkasa Pura I (Persero), dan PT Angkasa Pura II (Persero) pertumbuhan angkutan udara di Indonesia dalam satu dekade ini meningkat sangat pesat dengan pertumbuhan rata-rata diatas $20 \%$ dan merupakan pertumbuhan angkutan udara terbesar di kawasan Asia Pasifik dan dunia.

\section{Produk Perusahaan Penerbangan}

Menurut Agus Irianto (2009:2) dalam bukunya Managing Airline Reservation System, produk perusahaan penerbangan meliputi pesawat yang digunakan (type of aircraft), rute dan skedul atau jadwal penerbangan (time schedulue), pelayanan yang diberikan dari mulai sebelum keberangkatan dimana penumpang memulai memesan tempat (reservation), pembelian ticket (ticketing), check-in, boarding di station keberangkatan, selama penerbangan (in flight) station persinggahan (transit station) hingga di stasiun kedatangan.

1. Pesawat yang Digunakan

Penumpang dapat membedakan secara langsung produk suatu penerbangan dengan mengenal: jenis-jenis pesawat yang digunakannya, seperti pesawat bermesin jet atau baling-baling, tipe atau seri pesawat yang digunakan seperti tabel dibawah ini: 
Tabel 2

Jenis/Type Pesawat

\begin{tabular}{|c|c|c|c|}
\hline Keterangan & $\begin{array}{l}\text { WIDE BODY } \\
\text { AIRCRAFT }\end{array}$ & $\begin{array}{c}\text { NARROW BODY } \\
\text { AIRCRAFT }\end{array}$ & PESAWAT PERINTIS \\
\hline CIRI & $\begin{array}{l}\text { Memiliki izin terbang } \\
\text { trans-atlantik, di gunakan } \\
\text { untuk penerbangan jarak } \\
\text { menengah dan jarak jauh, } \\
\text { memerlukan landasan } \\
\text { yang jauh lebih panjang }\end{array}$ & $\begin{array}{l}\text { Biasa disebut pesawat lorong } \\
\text { tunggal, umumnya tidak memiliki } \\
\text { izin terbang trans-atlantik, di gunakan } \\
\text { untuk penerbangan regional }\end{array}$ & $\begin{array}{l}\text { Berukuran kecil, Dapat } \\
\text { menjangkau daerah } \\
\text { terpencil, bisa mendarat di } \\
\text { landasan pendek }\end{array}$ \\
\hline .Jenis/Type & $\begin{array}{l}\text { Airbus A300, Airbus } \\
\text { A330, Airbus A340, } \\
\text { Airbus A350, Airbus } \\
\text { A380, Boeing 747, } \\
\text { Boeing 767, Boeing 777, } \\
\text { Boeing 787Dreamliner, } \\
\text { dan lain-lain. }\end{array}$ & $\begin{array}{l}\text { Airbus A320 family, Boeing 707, } \\
\text { Boeing 720, Boeing 727, Boeing 737, } \\
\text { Boeing 757, Douglas DC-8, Tupolev } \\
\text { Tu-154, Tupolev Tu-204, Tupolev } \\
\text { Tu-334, Sukhoi SSJ 100, Vickers } \\
\text { VC10, BAC One-Eleven, Bae 146, } \\
\text { dan sebagainya. }\end{array}$ & $\begin{array}{l}\text { Cessna, Beechcraft, } \\
\text { Grumman, dan lain-lain }\end{array}$ \\
\hline
\end{tabular}

Setiap jenis pesawat tersebut memiliki kapasitas tempat duduk yang berbeda; komponen kelas yang bebeda; kompartemen kelas yang berbeda; desain dan warna ruangan kabinnya maupun tingkat kebisingan dalam kabin yang berbeda pula.

\section{Schedule atau Jadwal Penerbangan}

Schedule atau jadwal penerbangan meliputi rute penerbangan atau kota tujuan yang dilayani, penerbangan langsung (non stop flight), dengan persinggahan (transit) atau perpindahan pesawat (connecting flight), jam keberangkatan, kedatangan maupun di tempat persinggahan (departure, arrival, transit point), dioperasikan sendiri atau merupakan hasil kerja sama dengan penerbangan lain (joint operation), misalkan code-share serta jumlah frekuensi penerbangan.

\section{Pelayanan Yang Diberikan \\ Pelayanan yang diberikan meliputi} pelayanan di kantor penjualan yang secara fisik bisa berbentuk kantor maupun secara virtual melalui situs $W E B$, di bandara, ketepatan waktu keberangkatan dan kedatangan (On Time Performance dan Punctuality), pelayanan yang diberikan dalam pesawat (in fligt service). Keseluruhan pelayanan ini sering dikenal dengan istilah Pre-In and Post Flight Services.

\section{b. Pengertian Fasilitas Parkir}

Definisi parkir seperti yang tertuang di Undang-undang No. 22 Tahun 2009 tentang Lalu Lintas dan Angkutan Jalan, sebagaimana tercantum pada Pasal 1 angka 15 , adalah sebagai "keadaan tidak bergerak suatu kendaraan yang bersifat sementara karena ditinggalkan oleh pengemudinya".

Sedangkan fasilitas parkir, secara lebih rinci diatur dalam Pasal 43 ayat (1) yang menyebutkan: penyediaan fasilitas Parkir untuk umum hanya dapat diselenggarakan di luar Ruang Milik Jalan sesuai dengan izin yang diberikan.

Di dalam penjelasan Pasal 43 (1) pengertian "Parkir Umum" adalah tempat 
untuk memarkir kendaraan dengan dipungut biaya.

Sedang di dalam Kamus Besar Bahasa Indonesia, parkir didefinisikan sebagai "menghentikan atau menaruh (kendaraan bermotor) untuk beberapa saat di tempat yang sudah disediakan.

Termasuk dalam pengertian parkir adalah setiap kendaraan yang berhenti "STOP" pada tempat-tempat tertentu, baik yang dinyatakan dengan rambu lalu lintas ataupun tidak, serta tidak semata-mata untuk kepentingan menaikkan dan/atau menurunkan orang dan/atau barang (Iskandar Abubakar. 2011:3)

Menurut Munawar, A. (2004), fasilitas tempat parkir merupakan fasilitas pelayanan umum, yang merupakan faktor yang sangat penting dalam system transportasi di daerah perkotaan yang notabene merupakan tempat kegiatan umum seperti bandar udara. Dipandang dari sisi teknis lalu lintas, aktivitas parkir yang ada saat ini sangat mengganggu kelancaran arus lalu lintas, mengingat sebagian besar kegiatan parkir dilakukan di badan jalan, sehingga mengakibatkan turunnya kapasitas jalan dan terhambatnya arus lalu lintas dan penggunaan jalan menjadi tidak efektif

Menurut Munawar, A. (2004), fasilitas parkir merupakan manajemen lalu lintas perkotaan tata letak parkir kendaraan di suatu bandara dapat dibuat bervariasi, tergantung pada ketersediaan bentuk dan ukuran tempat serta jumlah dan letak pintu masuk dan keluar.

Menurut Ing dan Yanuardi (2007) fasilitas parkir secara garis besar dibagi 2 (dua) macam yaitu: fasilitas parkir di jalan (on-street parking) dan fasilitas parkir diluar jalan (off-street parking). Fasilitas parkir di jalan (on-street parking) adalah fasilitas parkir yang menggunakan tepi jalan sebagai ruang parkirnya, sedangkan fasilitas parkir diluar jalan (off-street parking) adalah fasilitas parkir kendaraan diluar tepi jalan umum, yang dibuat khusus sebagai penunjang kegiatan, berupa pelataran parkir dan atau gedung parkir.

\section{c. Pengertian Kepuasan Pelanggan Jasa}

Menurut Zulian (2010:78) kepuasan pelanggan jasa adalah evaluasi purna beli atau hasil evaluasi setelah membandingkan apa yang dirasakan dengan harapannya.

Menurut Suharto (2009:54) kepuasan pelanggan jasa adalah suatu kondisi yang menggambarkan terpenuhinya, bahkan terlampauinya harapan pelanggan atas suatu produk atau layanan yang dilakukan oleh pihak pengelola atau pelaku usaha.

Kepuasan pelanggan jasa adalah tingkat perasaan konsumen setelah membandingkan antara apa yang dia terima dan harapkan (Umar, 2005:65).

Menurut Philip Kotler dan Kevin Lane Keller (2007:177) yang dikutip dari buku Manajemen Pemasaran mengatakan bahwa kepuasan pelanggan jasa adalah perasaan senang atau kecewa seseorang yang 
muncul setelah membandingkan kinerja hasil produk yang dipikirkan terhadap kinerja yang diharapkan

Lebih lanjut menurut Philip Kotler dan Kevin Lane Keller (2007:177), dalam menentukan tingkat kepuasan pelanggan jasa, terdapat lima faktor yang harus di perhatikan oleh perusahaan yaitu:

1. Kualitas Produk

Konsumen akan merasa puas bila hasil evaluasi mereka menunjukkan bahwa produk yang mereka gunakan berkualitas.

2. Kualitas Pelayanan

Pelanggan akan merasa puas bila hasil evaluasi mereka menunjukkan bahwa pelayanan yang mereka rasakan sesuai keinginan mereka.

3. Emosional

Konsumen akan merasa bangga dan mendapatkan keyakinan bahwa orang lain akan kagum terhadap dia bila menggunakan jasa tertentu yang cenderung mempunyai tingkat kepuasan yang lebih tinggi. Kepuasan yang diperoleh bukan karena kualitas dari jasa tetapi nilai sosial yang membuat pelanggan menjadi puas terhadap jasa tertentu.

4. Harga

Jasa yang mempunyai kualitas yang sama tetapi menetapkan harga yang relatif murah akan memberikan nilai yang lebih tinggi kepada konsumennya.

5. Biaya
Konsumen atau pelanggan yang tidak perlu mengeluarkan biaya tambahan atau tidak perlu membuang waktu untuk mendapatkan suatu jasa cenderung puas terhadap jasa tersebut.

\section{METODOLOGI PENELITIAN}

\section{a. Tempat penelitian}

Penelitian ini dilakukan di parkir Bandara Halim Perdanakusuma, Jakarta Timur dengan mempertimbangkan bahwa disini dapat memberikan data yang terkait dengan penelitian dan pengumpulan data.

\section{b. Populasi dan sample}

Populasi dalam penelitian ini yaitu masyarakat yang menggunakan fasilitas parkir Halim Perdanakusuma Jakarta, teknik pengambilan sampel yang digunakan adalah Accidental Sampling yaitu dengan mengambil responden yang ada atau tersedia sebanyak 100 responden.

\section{c. Jenis data}

Jenis data yang digunakan dalam penelitian ini adalah kuantitatif yaitu pengumpulan data menggunakan instrumen penelitian, analisis data bersifat kuantitatif/statistik dengan tujuan untuk menguji hipotesis yang telah ditetapkan.

\section{d. Teknik Pengumpulan Data}

Teknik pengolahan data yang digunakan dalam penelitian ini adalah dengan melakukan pengukuran terhadap variabel independen dan varibel dependen. Alat ukur yang digunakan adalah dengan menggunakan 
Skala Likert yaitu skala yang digunakan untuk mengukur sikap, pendapat dan persepsi seseorang atau kelompok orang tentang fenomena sosial (Sugiyono, 2005:86). Setelah itu data yang dikumpulkan di buatkan tabulasi dengan menggunakan komputer pada program Spss versi 22.

\section{ANALISIS DATA}

\section{Uji Validitas}

Validitas adalah suatu ukuran yang menunjukkan bahwa variabel yang diukur benar-benar variabel yang hendak diteliti oleh peneliti (Cooper dan Schindler, dalam Zulganef, 2006).

Tabel 3

Hasil Uji Validitas

\begin{tabular}{|c|c|c|c|}
\hline $\begin{array}{c}\text { No } \\
\text { Pernyataann }\end{array}$ & $\mathbf{r}$ hitung & $\mathbf{r}$ tabel & Keterangan \\
\hline \multicolumn{4}{|c|}{ Peningkatan Frekuensi Penerbangan } \\
\hline 1 & 0.747 & 0,361 & Valid \\
\hline 2 & 0.710 & 0,361 & Valid \\
\hline 3 & 0.723 & 0,361 & Valid \\
\hline 4 & 0.546 & 0,361 & Valid \\
\hline 5 & 0.458 & 0,361 & Valid \\
\hline 6 & 0.497 & 0,361 & Valid \\
\hline \multicolumn{4}{|c|}{ Fasilitas Parkir } \\
\hline 1 & 0.531 & 0,361 & Valid \\
\hline 2 & 0.651 & 0,361 & Valid \\
\hline 3 & 0.558 & 0,361 & Valid \\
\hline 4 & 0.596 & 0,361 & Valid \\
\hline 5 & 0.398 & 0,361 & Valid \\
\hline \multicolumn{4}{|c|}{ Kepuasan Pelanggan } \\
\hline 1 & 0.695 & 0,361 & Valid \\
\hline 2 & 0.746 & 0,361 & Valid \\
\hline 3 & 0.756 & 0,361 & Valid \\
\hline 4 & 0.781 & 0,361 & Valid \\
\hline 5 & 0.706 & 0,361 & Valid \\
\hline 6 & 0.585 & 0,361 & Valid \\
\hline 7 & 0.407 & 0,361 & Valid \\
\hline 8 & 0.558 & 0,361 & Valid \\
\hline 9 & 0.461 & 0,361 & Valid \\
\hline 10 & 0.432 & 0,361 & Valid \\
\hline
\end{tabular}

Dari uji validitas yang telah dilakukan pada variabel peningkatan frekuensi penerbangan, fasilitas parkir dan kepuasan pelanggan dapat ditarik kesimpulan bahwa seluruh item yaitu $6,5,10$ item pernyataan dalam variabel tersebut valid karena memiliki $r_{\text {hitung }}>r_{\text {tabel. }}$

\section{Uji Realiabilitas}

Tabel 4 Hasil Uji Realibitas

\begin{tabular}{|c|c|c|c|c|}
\hline No & Variabel & $\begin{array}{c}\text { Nilai } \\
\text { Alpha }\end{array}$ & $\begin{array}{c}\text { Tingkat } \\
\text { Kehandalan }\end{array}$ & Keterangan \\
\hline 1. & $\begin{array}{c}\text { Peningkatan } \\
\text { Frekuensi } \\
\text { Penerbangan }\end{array}$ & 0.830 & 0,6 & Reliabel \\
\hline 2. & $\begin{array}{c}\text { Fasilitas } \\
\text { Parkir }\end{array}$ & 0.772 & 0,6 & Reliabel \\
\hline 3. & $\begin{array}{c}\text { Kepuasan } \\
\text { Pelanggan }\end{array}$ & 0.880 & 0,6 & Reliabel \\
\hline
\end{tabular}

Berdasarkan hasil uji reliabilitas yang telah dilakukan untuk semua variabel, di dapatkan skor cronbach's alpha untuk peningkatan frekuensi penerbangan, fasilitas parkir, dan kepuasan pelanggan secara berurutan sebesar $0.830,0.772,0.880$. Hal ini berarti pernyataan dari ketiga variabel tersebut dinyatakan reliabel karena nilai cronbach's alpha lebih besar dari tingkat kehandalan yaitu sebesar 0.6. 


\section{Uji Normalitas}

Tabel 5

Hasil Uji Normalitas

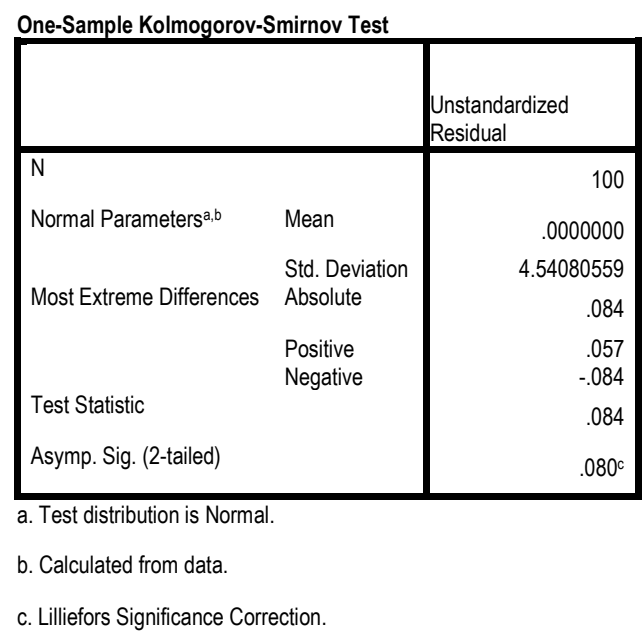

Hasil uji normalitas di atas menunjukkan bahwa nilai residual yang terdistribusi atau nilai signifikasi Asymp. Sig. (2-tailed) sebesar 0.080. Karena nilai signifikasinya lebih besar dari 0.05, dapat disimpulkan bahwa data variabel peningkatan frekuensi penerbangan, fasilitas parkir, dan kepuasan pelanggan dinyatakan berdistribusi normal

\section{Uji Multikolinearitas}

Uji multikolinearitas berguna untuk mengetahui apakah pada model regresi yang diajukan telah ditemukan korelasi kuat antar variabel bebas. Mengukur multikolinearitas dapat diketahui dengan melihat nilai Variance Inflation Factor (VIF) pada model regresi. Jika besar VIF $<5$ atau mendekati 1, maka mencerminkan tidak ada multikolinearitas (Husein Umar, 2008:80).
Tabel 6

Hasil Uji Multikolinearitas

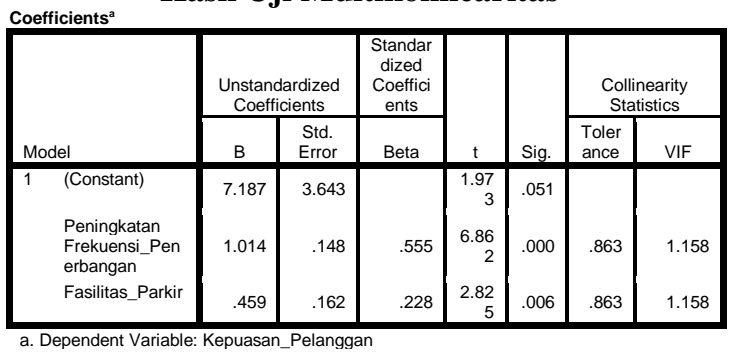

Berdasarkan hasil uji multikolinearitas pada table 5 diketahui nilai Variance Inflation Factor (VIF) untuk kedua variabel masingmasing sebesar 1.158, maka dapat ditarik kesimpulan bahwa tidak adanya multikolinearitas dalam model regresi yang digunakan.

\section{Uji Heteroskedasitas}

Uji heteroskedastisitas dilakukan untuk mengetahui apakah dalam sebuah model regresi terjadi ketidaksamaan varian dari residual suatu pengamatan kepengamatan lain. Jika varian dari residual suatu pengamatan kepengamatan lain tetap, disebut homokedastisitas, sedangkan untuk varian yang berbeda disebut heteroskedastisitas.

Tabel 7

Correlations

Hasil Uji Heteroskedasitas

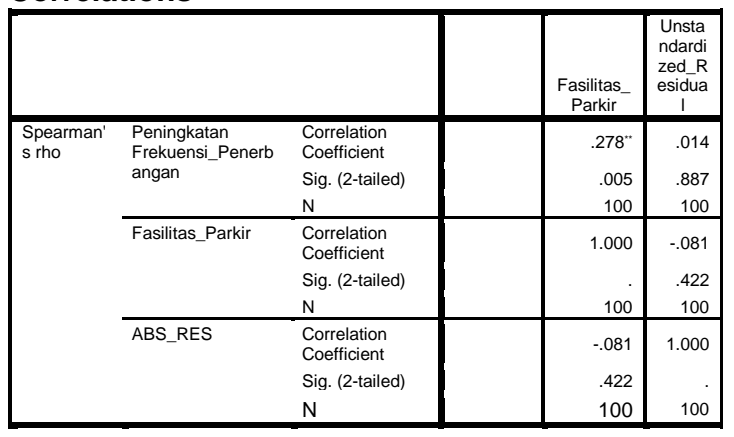

${ }^{* *}$. Correlation is significant at the 0.01 level (2-tailed). 
Pada tabel, di atas menunjukkan bahwa korelasi antara peningkatan frekuensi penerbangan dan unstandardized residual menghasilkan nilai signifikasi 0.887 dan korelasi antara fasilitas parkir dengan unstandardized residual menghasilkan nilai signifikasi 0.422. Maka itu, dapat ditarik kesimpulan bahwa pada model regresi tidak ditemukan adanya masalah heteroskedastisitas, hal ini dikarenakan nilai signifikasi korelasi lebih besar dari 0.05.

Uji Hipotesis secara Parsial

Tabel 8

Hasil Uji t Variabel Peningkatan Frekuensi Penerbangan

\begin{tabular}{|c|c|c|c|c|c|}
\hline \multirow[b]{2}{*}{ Model } & \multicolumn{2}{|c|}{$\begin{array}{l}\text { Unstandardized } \\
\text { Coefficients }\end{array}$} & $\begin{array}{c}\text { Standardize } \\
d \\
\text { Coefficients } \\
\end{array}$ & \multirow[b]{2}{*}{ T } & \multirow[b]{2}{*}{ Sig. } \\
\hline & B & Std. Error & Beta & & \\
\hline - (Constant) & 12.371 & 3.258 & & 3.797 & $\begin{array}{r}.00 \\
0\end{array}$ \\
\hline $\begin{array}{l}\text { Peningkatan } \\
\text { frekuensi } \\
\text { penerbangan }\end{array}$ & 1.168 & .142 & .639 & 8.222 & $\begin{array}{r}.00 \\
0\end{array}$ \\
\hline
\end{tabular}

a. Dependent Variable: Kepuasan Pelanggan

Berdasarkan tabel 4.32, maka dapat dilihat bahwa $t_{\text {hitung }}$ untuk variabel peningkatan frekuensi penerbangan sebesar 8.222. Nilai thitung kemudian dibandingkan dengan nilai $\mathrm{t}_{\text {tabel, }}$ yang dicari pada $\alpha=5 \%: 2$ $=2,5 \%$ (uji 2 sisi) dengan derajat kebebasan (df) n-k-1 atau (97) 100-2-1. Dimana n adalah jumlah sampel dan $\mathrm{k}$ adalah jumlah variabel bebas. Berdasarkan perhitungan tersebut, didapat $t_{\text {tabel }}$ sebesar 1.984. Ini berarti $t_{\text {hitung }}>t_{\text {tabel }}$.

Dengan itu, kesimpulan yang dapat ditarik adalah $\mathrm{H}_{0}$ ditolak dan $\mathrm{H}_{\mathrm{a}}$ diterima. Hipotesisnya adalah peningkatan frekuensi penerbangan memiliki pengaruh positif dan signifikan terhadap kepuasan pelanggan pada parkir Bandara Halim Perdanakusuma.

Tabel 9

Coefficients $^{\mathrm{a}}$

\section{Hasil Uji t Variabel Fasilitas Parkir}

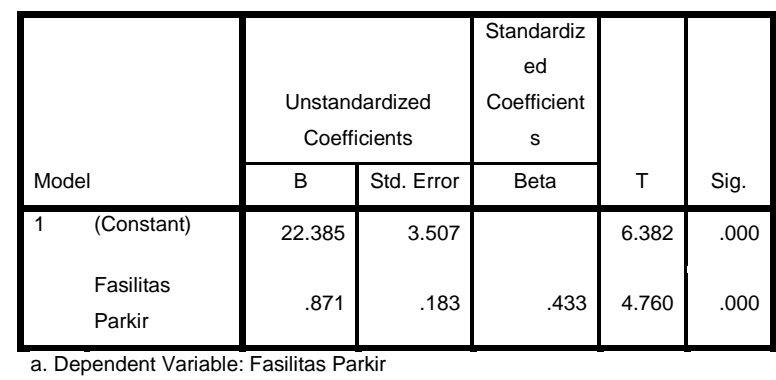

Berdasarkan table di atas maka dapat dilihat bahwa $t_{\text {hitung }}$ untuk variabel fasilitas parkir sebesar 4.760. Nilai thitung kemudian dibandingkan dengan nilai $\mathrm{t}_{\text {tabel, }}$ yang dicari pada $\alpha=5 \%: 2=2,5 \%$ (uji 2 sisi) dengan derajat kebebasan (df) n-k-1 atau (97) 100-21. Dimana $\mathrm{n}$ adalah jumlah sampel dan $\mathrm{k}$ adalah jumlah variabel bebas. Berdasarkan perhitungan tersebut, didapat $t_{\text {tabel }}$ sebesar 1.984. Ini berarti $t_{\text {hitung }}>\mathrm{t}_{\text {tabel }}$.

Dengan itu, kesimpulan yang dapat ditarik adalah $\mathrm{H}_{0}$ ditolak dan $\mathrm{H}_{\mathrm{a}}$ diterima. Hipotesisnya adalah fasilitas parkir memiliki pengaruh positif dan signifikan terhadap kepuasan pelanggan pada parkir Bandara Halim Perdanakusuma.

Tabel 10

Hasil Uji Hipotesis secara simultan

ANOVA $^{\mathrm{a}}$

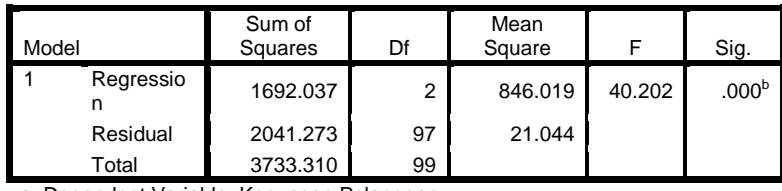

a. Dependent Variable: Kepuasan Pelanggan

b. Predictors: (Constant), Peningkatan Frekuensi Penerbangan, Fasilitas Parkir

Berdasarkan tabel di atas didapat nilai $F_{\text {hitung }}$ sebesar 40.202. Nilai $F_{\text {hitung }}$ kemudian dibandingkan dengan nilai $\mathrm{F}_{\text {tabel }}$ 
yang dicari dengan tingkat keyakinan 95\%, $\alpha$ $=5 \%$, dengan df 1 (jumlah variabel-1) atau 3-1 = 2, dan df 2 (n-k-1) atau 100-2-1. Berdasarkan perhitungan tersebut, didapat $F_{\text {tabel }}$ 3.090. Dengan demikian $F_{\text {hitung }}>F_{\text {tabel }}$. Signifikasi pada uji F sebesar 0.000, dengan demikian hal ini berarti lebih kecil dari 0.05. Kesimpulan yang dapat diambil, $\mathrm{H}_{0}$ ditolak dan $\mathrm{H}_{\mathrm{a}}$ diterima. Hipotesisnya adalah peningkatan frekuensi penerbangan dan fasilitas parkir secara bersama-sama memiliki pengaruh positif terhadap kepuasan pelanggan pada parkir Bandara Halim Perdanakusuma.

\section{PEMBAHASAN}

\section{a. Peningkatan Frekuensi Penerbangan}

Berdasarkan distribusi responden: saya melihat bahwa kebijakan/regulasi penerbangan saat ini sudah cukup jelas, menyatakan setuju sebesar 59\%. Kemudian, berdasarkan distribusi responden: saya merasakan bahwa pengaturan regulasi tentang perizinan, harga (tarif), rute, dan keselamatan penerbangan cukup bagus, menyatakan setuju sebesar $62 \%$. Selanjutnya, berdasarkan distribusi responden: saya melihat bahwa regulasi penerbangan saat ini sudah dilaksanakan dengan baik, menyatakan setuju sebesar 54\%. Sementara berdasarkan distribusi responden: saya menilai bahwa minat masyarakat untuk menggunakan moda transportasi udara semakin meningkat, menyatakan sangat setuju sebesar $50 \%$. Lebih lanjut, berdasarkan distribusi responden: saya lebih suka menggunakan transportasi udara dari atau ke Bandara Halim Perdanakusuma, menyatakan setuju sebesar $38 \%$. Berdasarkan distribusi responden: saya sering menggunakan pesawat Batik Air, menyatakan setuju sebesar $31 \%$. Berdasarkan distribusi responden peningkatan frekuensi penerbangan, mayoritas menyatakan setuju yaitu sebanyak 5 dari total 6 distribusi pernyataan responden atau $83,33 \%$ dari total secara keseluruhan responden. Selanjutnya, berdasarkan uji linearitas, maka variabel peningkatan frekuensi penerbangan dan variabel kepuasan pelanggan memiliki hubungan yang linear dengan nilai signifikan sebesar 0,015 lebih kecil dari nilai yang disyaratkan yaitu sebesar 0,05. Kemudian, berdasarkan uji homogenitas, maka variabel peningkatan frekuensi penerbangan dan variabel kepuasan pelanggan memiliki hubungan yang sama (homogen) dengan nilai signifikan sebesar 0,562 lebih besar dari nilai yang disyaratkan yaitu sebesar 0,05. Berdasarkan uji $t$ variabel peningkatan frekuensi penerbangan, memiliki nilai thitung $>\mathrm{t}_{\text {tabel }}$ yaitu sebesar $8,222>1,984$. Selanjutnya, nilai signifikannya sebesar 0,00 lebih kecil dari nilai yang disyaratkan yaitu sebesar 0,05. Artinya peningkatan frekuensi penerbangan memiliki pengaruh positif dan signifikan terhadap kepuasan pelanggan pada parkir Bandara Halim Perdanakusuma. Berdasarkan uji koefisien determinasi, persentase pengaruh variabel peningkatan 
frekuensi penerbangan terhadap variabel kepuasan pelanggan yaitu sebesar 40.8\%, sedangkan $59.2 \%$ sisanya dipengaruhi oleh variabel lain. Sementara itu, nilai adjusted $\mathrm{R}^{2}$ sebesar 0.402. Berdasarkan uji korelasi sederhana (r) didapat korelasi antara peningkatan frekuensi penerbangan dengan kepuasan pelanggan (r) adalah 0,639. Hal ini menunjukkan bahwa terjadi hubungan yang kuat antara peningkatan frekuensi penerbangan dengan kepuasan pelanggan. Sedangkan arah hubungan adalah positif karena nilai $r$ positif, berarti semakin tinggi peningkatan frekuensi penerbangan maka semakin meningkatkan kepuasan pelanggan.

\section{b. Fasilitas Parkir}

Berdasarkan distribusi responden: saya memperhatikan bahwa kawasan terbangun di Bandara Halim Perdanakusuma cukup banyak, menyatakan setuju sebesar $46 \%$. Kemudian, berdasarkan distribusi responden: saya melihat bahwa cukup banyak dan padat kegiatan di Bandara Halim Perdanakusuma, menyatakan setuju sebesar $41 \%$. Selanjutnya, berdasarkan distribusi responden: saya menilai bahwa masyarakat cukup banyak yang tertarik melakukan berbagai aktifitas di Bandara Halim Perdanakusuma, menyatakan setuju sebesar $48 \%$. Sementara berdasarkan distribusi responden: saya melihat bahwa cukup banyak karyawan yang bekerja di Bandara Halim Perdanakusuma, menyatakan setuju sebesar 54\%. Berdasarkan distribusi responden: saya melihat bahwa kepemilikan kendaraan pribadi yang beroperasi di
Bandara Halim Perdanakusuma cukup banyak, menyatakan setuju sebesar $43 \%$. Berdasarkan distribusi responden fasilitas parkir, mayoritas menyatakan setuju yaitu sebanyak 5 dari total 5 distribusi pernyataan responden atau $100 \%$ dari total secara keseluruhan responden. Selanjutnya, berdasarkan uji linearitas, maka variabel fasilitas parkir dan variabel kepuasan pelanggan memiliki hubungan yang linear dengan nilai signifikan sebesar 0,001 lebih kecil dari nilai yang disyaratkan yaitu sebesar 0,05. Kemudian, berdasarkan uji homogenitas, maka variabel fasilitas parkir dan variabel kepuasan pelanggan memiliki hubungan yang sama (homogen) dengan nilai signifikan sebesar 0,736 lebih besar dari nilai yang disyaratkan yaitu sebesar 0,05. Sementara itu, berdasarkan uji $\mathrm{t}$ variabel fasilitas parkir, memiliki nilai $\mathrm{t}_{\text {hitung }}>\mathrm{t}_{\text {tabel }}$ yaitu sebesar $4,760>1,984$. Selanjutnya, nilai signifikannya sebesar 0,00 lebih kecil dari nilai yang disyaratkan yaitu sebesar 0,05. Artinya fasilitas parkir memiliki pengaruh positif dan signifikan terhadap kepuasan pelanggan pada parkir Bandara Halim Perdanakusuma. Berdasarkan uji koefisien determinasi, persentase pengaruh variabel fasilitas parkir terhadap variabel kepuasan pelanggan yaitu sebesar $11.8 \%$, sedangkan $88.2 \%$ sisanya dipengaruhi oleh variabel lain. Sementara itu, nilai adjusted $\mathrm{R}^{2}$ sebesar 0.180. Berdasarkan uji korelasi sederhana (r) didapat korelasi antara fasilitas parkir dengan kepuasan pelanggan (r) adalah 0,433 . Hal ini 
menunjukkan bahwa terjadi hubungan yang kuat antara fasilitas parkir dengan kepuasan pelanggan. Sedangkan arah hubungan adalah positif karena nilai $r$ positif, berarti semakin tinggi fasilitas parkir maka semakin meningkatkan kepuasan pelanggan.

c. Peningkatan Frekuensi Penerbangan dan Fasilitas Parkir Secara Simultan Terhadap Kepuasan Pelanggan

Berdasarkan distribusi responden: saya merasakan bahwa pelayanan petugas di Bandara Halim Perdanakusuma cukup cepat, menyatakan setuju sebesar 51\%. Kemudian, berdasarkan distribusi responden: saya melihat bahwa di Bandara Halim Perdanakusuma pelayanan informasi cukup tepat/akurat seperti yang diharapkan, menyatakan setuju sebesar $60 \%$. Selanjutnya, berdasarkan distribusi responden: saya merasakan keamanan di Bandara Halim Perdanakusuma cukup bagus, menyatakan setuju sebesar $51 \%$. Sementara berdasarkan distribusi responden: saya merasakan bahwa petugas di Bandara Halim Perdanakusuma cukup ramah dan sopan, menyatakan sangat setuju sebesar $41 \%$. Lebih lanjut, berdasarkan distribusi responden: saya merasakan dalam melakukan setiap aktifitas di Bandara Halim Perdanakusuma cukup nyaman, menyatakan setuju sebesar $49 \%$. Berdasarkan distribusi responden: saya menilai untuk keperluan tempat pembayaran atau transaksi seperti ATM, Bank, mudah ditemukan di Bandara Halim Perdanakusuma, menyatakan setuju sebesar
50\%. Kemudian, berdasarkan distribusi responden: saya menilai bahwa wawasan dan kemampuan petugas di Bandara Halim Perdanakusuma cukup bagus, menyatakan setuju sebesar 54\%. Selanjutnya, berdasarkan distribusi responden: saya melihat fasilitas dan peralatan yang ada di Bandara Halim Perdanakusuma cukup lengkap dan bagus, menyatakan setuju sebesar $45 \%$. Sementara berdasarkan distribusi responden: saya merasakan bahwa informasi tentang Bandara Halim Perdanakusuma cukup jelas, menyatakan setuju sebesar $56 \%$.

Lebih lanjut, berdasarkan distribusi responden: saya menilai simbol atau tandatanda yang ada di Bandara Halim Perdanakusuma cukup jelas, menyatakan setuju sebesar $48 \%$. Berdasarkan distribusi responden kepuasan pelanggan, mayoritas menyatakan setuju yaitu sebanyak 9 dari total 10 distribusi pernyataan responden atau $90 \%$ dari total secara keseluruhan responden. Selanjutnya, berdasarkan uji normalitas, maka data variabel peningkatan frekuensi penerbangan, fasilitas parkir, dan kepuasan pelanggan dinyatakan memenuhi syarat dengan nilai signifikan sebesar 0,08 lebih besar dari nilai yang disyaratkan yaitu sebesar 0,05. Kemudian, berdasarkan uji multikolinearitas, maka variabel peningkatan frekuensi penerbangan dan variabel fasilitas parkir menyatakan bahwa tidak adanya multikolinearitas dengan nilai VIF sebesar 1,158 kurang dari nilai yang disyaratkan yaitu sebesar 5. Sementara itu, berdasarkan 
uji heteroskedastisitas, variabel peningkatan frekuensi penerbangan memiliki nilai signifikan sebesar 0,887 dan variabel fasilitas parkir memiliki nilai signifikan sebesar 0,442 , artinya tidak ditemukannya adanya masalah heteroskedastisitas hal ini dikarenakan nilai signifikan variabel bebas lebih besar dari nilai yang disyaratkan yaitu sebesar 0,05. Berdasarkan uji autokolinearitas, variabel peningkatan frekuensi penerbangan dan variabel fasilitas parkir dengan nilai Durbin Watson 2,422, artinya tidak dapat disimpulkan keberadaan autokorelasi. Selanjutnya, berdasarkan uji $\mathrm{F}$ variabel peningkatan frekuensi penerbangan dan variabel fasilitas parkir, memiliki nilai $\mathrm{t}_{\text {hitung }}>\mathrm{t}_{\text {tabel }}$ yaitu sebesar $40.202>30.90$. Selanjutnya, nilai signifikannya sebesar 0,00 lebih kecil dari nilai yang disyaratkan yaitu sebesar 0,05 . Artinya peningkatan frekuensi penerbangan dan fasilitas parkir secara bersama-sama memiliki pengaruh positif yang signifikan terhadap kepuasan pelanggan pada parkir Bandara Halim Perdanakusuma. Sementara itu, berdasarkan uji koefisien determinasi, secara simultan persentase pengaruh variabel peningkatan frekuensi penerbangan dan fasilitas parkir terhadap variabel kepuasan pelanggan yaitu sebesar $45,3 \%$, sedangkan $54,7 \%$ sisanya dipengaruhi oleh variabel lain. Sementara itu, nilai adjusted $\mathrm{R}^{2}$ sebesar 0.442 .

\section{KESIMPULAN}

Berdasarkan penelitian yang dilakukan maka ditarik kesimpulan bahwa :

1. Terbukti secara empiris peningkatan frekuensi penerbangan $\left(\mathrm{X}_{1}\right)$ memiliki pengaruh positif dan signifikan terhadap kepuasan pelanggan $(\mathrm{Y})$ di parkir Bandara Halim Perdanakusuma.

2. Terbukti secara empiris fasilitas parkir $\left(\mathrm{X}_{2}\right)$ memiliki pengaruh positif dan signifikan terhadap kepuasan pelanggan (Y) di parkir Bandara Halim Perdanakusuma

3. Terbukti secara empiris peningkatan frekuensi penerbangan $\left(\mathrm{X}_{1}\right)$ dan fasilitas parkir $\left(\mathrm{X}_{2}\right)$ secara bersama-sama memiliki pengaruh positif dan signifikan terhadap kepuasan pelanggan (Y) di parkir Bandara Halim Perdanakusuma.

\section{DAFTAR PUSTAKA}

Abubakar, Iskandar. 2011. PARKIR

Pengantar Perencanaan dan

Penyelenggara Fasilitas Parkir,

TRANSINDO Gastama Media

Adisasmita, Sakti Adji. 2014. Tatanan Bandar Udara Nasional, GRAHA ILMU, Jogyakarta.

Cholid, Christian, Basuki, dan Adi. 2010. Pengertian dan Istilah Penerbangan Sipil, PT. Raja Grafindo Persada, Jakarta.

Fathoni, Abdullah, 2014. Manajemen Kebandarudaraan Strategis, Kooperasi BPA, Jakarta. 
Irianto, Agus. 2009. Managing Airline Reservation System, Rajagrafindo Persada, Jakarta.

Manurung, Laurensius. 2010. Strategi dan Inovasi Model Bisnis Meningkatkan Kinerja Usaha, Elex Media Komputindo, Jakarta.

Priyatno, Duwi. 2010. Teknik Mudah dan Cepat Melakukan Analisis Data Penelitian dengan SPSS dan Tanya Jawab Ujian Pendadaran, Gaya Media, Yogyakarta.

Sugiyono. 2011. Metode Penelitian Kuantitatif, Kualitatif dan $R \& D$, Alfabeta, Bandung.

Tan Lie Ling dan Arien Hadian Yanuardi. 2007. Tinjauan Kepuasan Pelanggan Terhadap Kualitas Pelayanan Parkir Basement di Pusat Perbelanjaan Bandung Supermall. Bandung: Jurnal Teknik Sipil Vol. 3 No. 2:14119331. 